\title{
44 års virksomhed i opdragelsens tjeneste
}

\author{
Afskedsforelæsning den 31. januar, 1946 på Tønder \\ Statsseminarium
}

\section{Af Claus Eskildsen}

Blandt de manuskripter afdøde bibliotekar Poul Kürstein, leder af Studieafdelingen på Dansk Centralbibliotek, havde fået overdraget, forelå ved hans død seminarielærer Claus Eskildsens afskedsforelæsning, som her bringes med tilladelse fra familien.

I forelæsningen redegør Claus Eskildsen for sin pædagogiske uddannelse og for sin særegne nationale udvikling. Claus Eskildsen strejfer i forelæsningen sit historiske arbejde. Claus Eskildsen var fra Historisk Samfunds oprettelse i 1922 til sin død i 1947 medlem af styrelsen for Historisk Samfund. I 1924 tog han initiativet til udgivelse af Sønderjysk Månedsskrift, som han redigerede til sin død, med amtslæge Lausten Thomsen, Tønder, senere Åbenrå som medredaktør, og senere viceskoleinspektør Werner Christiansen, Tønder som praktisk hjælper. I 1936 udgav Claus Eskildsen: Dansk Grænselære, i 1942: Den sønderjyske befolknings slægtsforbindelser og året efter jubilæumsbogen: Tønder 1243-1943.

Claus Eskildsen var tillige en stærkt benyttet foredragsholder om såvel historiske som aktuelle emner. Døden indhentede ham under en foredragsrejse på en storebæltsfærge den 7. oktober 1947.

I.

På falderebet skal jeg se tilbage over 44 års arbejde i opdragelsens tjeneste, 40 års virksomhed på dette sted, 40 skelsættende år i seminariets, i købstaden Tønders, i Sønderjyllands, i Danmarks, i hele verdens historie. Jeg ønskede i stedet for at holde Dem et foredrag om et aktuelt emne, thi det er en ubehagelig opgave at skulle fortælle om sig selv, selv om man, så godt det kan gøres, prøver på at stille egne oplevelser og erfaringer ind $i$ en storre ramme. Forstanderen ${ }^{1}$ holdt imidlertid fast ved det opgivne emne, og jeg skal være loyal til det sidste og altså en time trætte Dem med fortællingen om Claus Eskildsen, den danske bondedreng, der blev lærer i den preussiske stats tjeneste, blev 
Claus Eskildsen (1881-1947). ( $H i$ storiske Samlinger for Senderjylland).

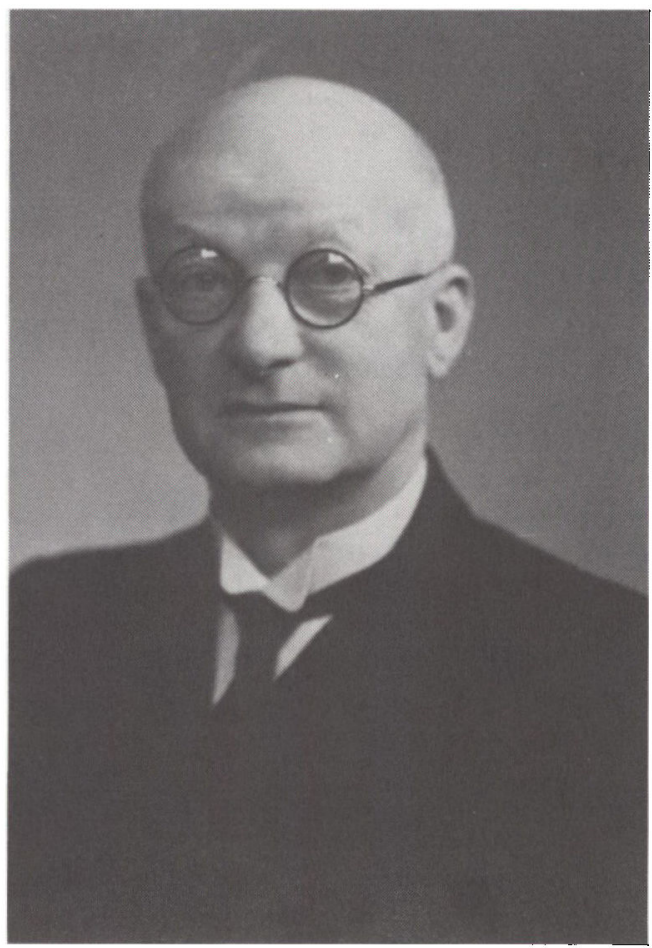

kongelig preussisk seminarielærer, der som Feldwebel traskede fra by til by i Litaven og Polen, Belgien og Frankrig, der blev dansk seminarielærer og som foredragsholder nu farter landet rundt, og som dog altid med alle rødderne var bundet fast til hjemstavnen, det smukke og omstridte grænseland Sønderjylland, som ingen af dets børn kan tænke sig at bytte bort for nogen anden plet på jorden.

Vi var 4 brødre og 3 søstre i søskendeflokken på den lille gård i læ af den store bakke mellem grønne bøgeskove og den blå Åbenrå fjord. Vor far døde tidligt; ${ }^{2}$ vi 4 brødre kunne ikke forsørges som landmænd alle sammen, og da man påstod, at Claus var begavet, skulle han læse, det vil sige, blive lærer; anden vej var der ikke tale om, som forholdene lå dengang. Realskoler kendtes slet ikke; ud over gymnasierne i Flensborg og Haderslev, hvortil senere kom en overrealskole i Sønderborg, var der ingen højere skoler $i$ hele landsdelen, og ingen kunne derfor tænke på en anden vej end lærervejen for en dreng fra landsbyen, der skulle holdes til bogen. Heldigvis var det dog for mig og mit hjem ved valget af livsstilling ikke, som vel for så mange, blot et spørgsmål af 
materiel art, der skulle afgøres. Jeg husker, at min mor, da beslutningen blev taget, sagde: "Han skal nok blive en god lærer! Claus har altid været glad for små børn!« Jeg vil da slutte min lærergerning med først at bekende, at jeg takker min mor og min Gud for, at jeg fik den dejligste gerning, en mand kan blive velsignet med, denne, hver dag at blive stillet over for lysende, friske, glade barneøjne og få lov til at være med til at undervise og opdrage den kommende slægt, fremtidens håb. Mit første ønske for Dem alle skal være, at De engang om mange år, når De går fra borde, også kan sige Gud tak for, at De blev udvalgt til at være folkets lærere.

Alligevel har jeg flere gang i mit liv under nationale samvittighedsbrydninger rettet anker mod skæbnen og mod mennesker, at de ikke hindrede, at jeg blev lærer $\mathrm{i}$ den tyske skoles tjeneste og derved blev afskåret fra at virke $i$ den sags tjeneste, der var en livssag for mit barndomshjem. Jeg har aldrig glemt, at min mor engang, da man forarget drøftede tyskernes voldsmetoder, busede ud med ordene: "Jeg tror, Vorherre er dansk!« i den betydning, at den dybeste sandhed og ret $\mathrm{i}$ det dansk-tyske grænselandsspørgsmål og dermed pantet på den endelige sejr var på dansk side. Min morfar var en af danskhedens bedste mænd i Felsted sogn, og pastor Mørk-Hansens meddeler til de oplysninger om nordslesvigske forhold, han leverede til hovedstadspressen; min far havde kæmpet som dansk soldat i 1864 foran Danevir-

Hjemmet i Felstedskov, tegnet den 9. oktober 1900. Fra Claus Eskildsens skitsebog. (Privateje) 
ke og i Nørrejylland, havde senere opteret for Danmark og havde helt til sin død måttet leve en optants liv på den gamle slægtsgård; i min mors fotografialbum sad på første side den folkekære kong Frederik VII, på den anden pastor Mørk-Hansen og hustru. En dreng fra dette hjem burde ikke have været sendt ind i den preussiske skoles tjeneste. Jeg selv kunne ikke $\mathrm{i}$ den unge alder forudse de store samvittighedsbrydninger, dette skulle medføre, min mor vel heller ikke; men jeg bebrejder danske naboer, at de ikke var mere forudseende. Man har fra dansk og tysk side yndet at fremstille det danske arbejde i preussertiden som ovenud godt organiseret. Dette passer ikke; hvert hjem skøttede sig nærmest selv, og hvert år lod man toppen af landboungdommen gå på tyske seminarier eller ad andre veje, der skulle betyde deres varige tab for den danske sag, ofte endog gøre dem til fremtidige førere i kampen mod deres barndomshjems nationale sag. Det burde have været en af de vigtigste opgaver for de danske nationale organisationer at skabe et omfattende tillidsmandsapparat til at hindre, at de mest begavede unge havnede $\mathrm{i}$ de tyske rækker.

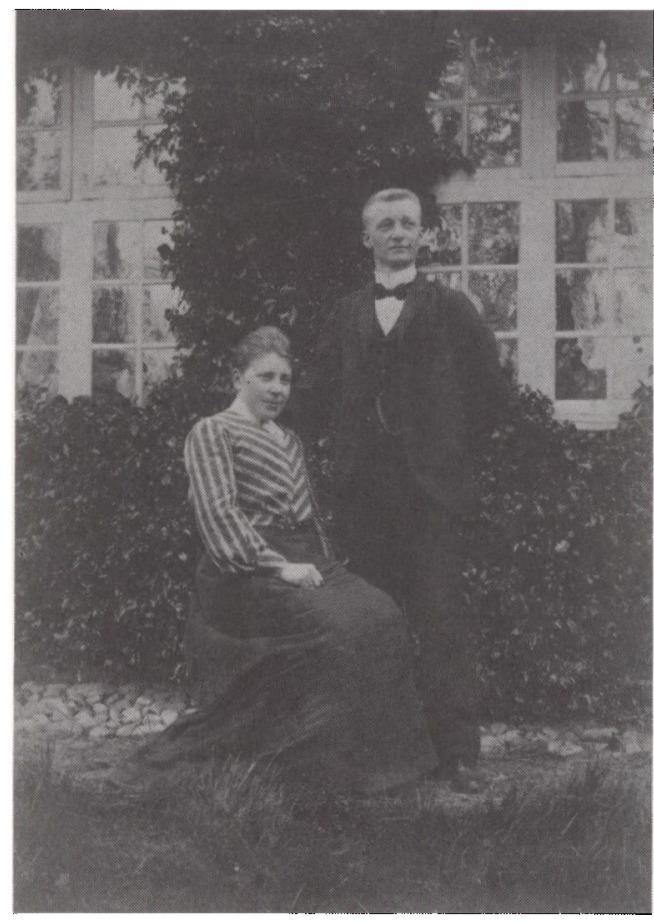

Claus Eskildsen med hustruen Caroline Johanne, fodt Lorenzen. Parret er fotograferet foran skolen $i$ Sad $i$ 1903 eller 1904. (Privateje). 
$\mathrm{Nu}$ gik de ikke blot tabt; men de enkelte mennesker blev, hvad de selv ikke anede noget om i så ung en alder, ført ud i de vanskeligste samvittighedskonflikter, og den nationale forkvakling, der ofte blev resultatet, bredte sig hos ikke så få til en forkvakling på hele moralens område, et grænselandsfænomen, vi også har kunnet iagttage efter 1920. Det vil være på sin plads, at jeg nu på falderebet siger et par ord om mine egne nationale brydninger, ikke fordi min person har noget at betyde, men fordi min udvikling er typisk for mange unge nordslesvigere, af hvilke det gik de fleste værre, end det gik mig.

Jeg var en absolut bevidst dansk dreng, da jeg med 15 år kom på præparandanstalten i Åbenrå, og jeg harmedes, hver gang forstander Krieger kom med sine hadefulde og hånende udfald mod danskerne. Vi var fra min klasse 2 sønderjyder, der af nationale grunde ikke gik til et af de to nordslesvigske seminarier, i Tønder og Haderslev, der i nogen grad kunne kaldes fortyskningsanstalter, men valgte at gå til Eckernførde, hvor det dansk-tyske spørgsmål ikke spillede den mindste rolle. På seminariet undlod jeg at søge statsunderstøttelse, skønt jeg efter mit hjems økonomiske forhold godt kunne have fået; jeg ville stå frit efter endt uddannelse og ikke skylde preusserne noget, som man skulle betale tilbage, når man gik ud af preussisk statstjeneste og søgte ind i Hamborgs skolevæsen, hvor mange dansksindede lærere dengang fandt et fristed.

Skæbnen førte mig i stedet for til denne egn, hvor jeg fandt min kone $^{3}$ og derfor blev hængende, og hvor de nationale modsætninger i det mindste i Ubjerg sogn og Tønder købstad - heller ikke var særlig skarpe på på grund af den tyske absolutte overvægt. Det tydeligste bevis er, at Tønder som en af de allersidste byer, først i 1909 fik en afdeling af den tyske forening, at byrådet ved denne lejlighed officielt advarede borgerne imod at indtræde som medlemmer, og at byrådet ligeledes nægtede at give tilladelse til opstilling af et kejser-Wilhelmmindesmærke på torvet; på Haderslev torv stod et mindesmærke for kejser Wilhelm, i Tønder måtte den store kejser nøjes med at blive puttet afsides hen på kirkepladsen. Der var i Tønder ikke den store mistænksomhed og jagt på danskere som andre steder i Nordslesvig; man kunne bevare sit danske sindelag nogenlunde $\mathrm{i}$ fred, når man gemte sig godt. I min egen og min kones danske familiekreds vidste alle, at jeg var dansksindet, og mistænkt var jeg også hele tiden hos tyskerne. I 1912 sagde min kollega Grøndahl: »Eskildsen ist ein verkappter Däne!« I 1913 sagde apoteker Meubrink, da han havde fået lov til at læse den danske slægtsbog, jeg havde skrevet: »Nu forstår 
jeg godt, at folk siger om Dem, at De er dansksindet; De kan jo ikke være andet! «

Værre var det at være $\mathrm{i}$ fred med sin egen samvittighed. Det var $\mathrm{i}$ længden uudholdeligt at skulle leve en elendig hyklers liv, at skulle agere tysk udadtil og være dansk i sindet. Mange af mine landsmænd blev som preussiske tjenestemænd i de forskellige etater stillet over for denne konflikt. Helt enkelt, de stærkeste og bedste, brød af og gik ud af statens tjeneste; et større tal sprang hovedkuls over $i$ det tyske og optrådte som fanatiske renegater, et typisk overkompenseringsfænomen; andre søgte langsomt at arbejde sig over til enheden mellem deres sind og det, de ifølge deres livserhverv skulle være. For nogle lykkedes det helt, andre nåede det aldrig.

Jeg hørte til den sidste gruppe. Hensynet til min familie og den gerning, jeg holdt af, forbød mig at forlade min stilling. Jeg måtte se at holde mit danske sindelag nede og finde over til det tyske. Jeg lukkede derfor bevidst af for al dansk påvirkning, idet jeg afholdt mig fra at læse danske aviser og bøger, og jeg søgte forbindelse med det bedste $\mathrm{i}$ tysk kultur. Jeg nåede aldrig til vejs ende, men nåede et godt stykke frem, takket være mit arbejde til mine eksaminer, der førte mig til en følelse af at være knyttet til tysk kultur. Jeg vil dog nævne, at jeg blev stødt tilbage, hver gang »Tondernsche Zeitung« eller andre tyske grænselandsblade bragte deres hånende, hadefulde angreb mod det danske, eller der rettedes angreb mod det danske fra anden side. $\mathrm{Da}$ den tyske forening den 16. januar 1909 f.eks. foretog sin berømte "Sturm auf Tondern«, og jeg i den anledning blev bedt om at stenografere talerne til den lokale avis, opsøgte jeg $\mathrm{i}$ aftenens mørke redaktør Peder Skovrøy ${ }^{4}$ og tilbød ham et referat også, så var samvittigheden beroliget på dette punkt!

Ud fra mine egne livserfaringer kan det være aktuelt at udtale følgende ved denne lejlighed: Det danske arbejdes mål skal altid være at gøre Sønderjylland til et rent dansk land; dette sker ikke ved at håne og skræmme og true tyskerne, men ved positivt og i frihedens og tolerancens ånd at udbrede dansk åndsliv.

Fra tysk side har man som sagt kaldt mig en "verkappter Däne«; fra dansk side har man i modsætning dertil påstået, at jeg var blevet helt tysk og bl.a. har holdt taler på Knivsbjerg og på kejserens fødselsdag. Måske går snakken endnu, og derfor vil jeg endnu engang, mens jeg er i live, søge at aflive myten ved at sige, at jeg aldrig har holdt tale på Knivsbjerg, hvad enhver let kan overbevise sig om ved at læse avisreferaterne fra denne tid. Som seminariets gymnastiklærer førte jeg 


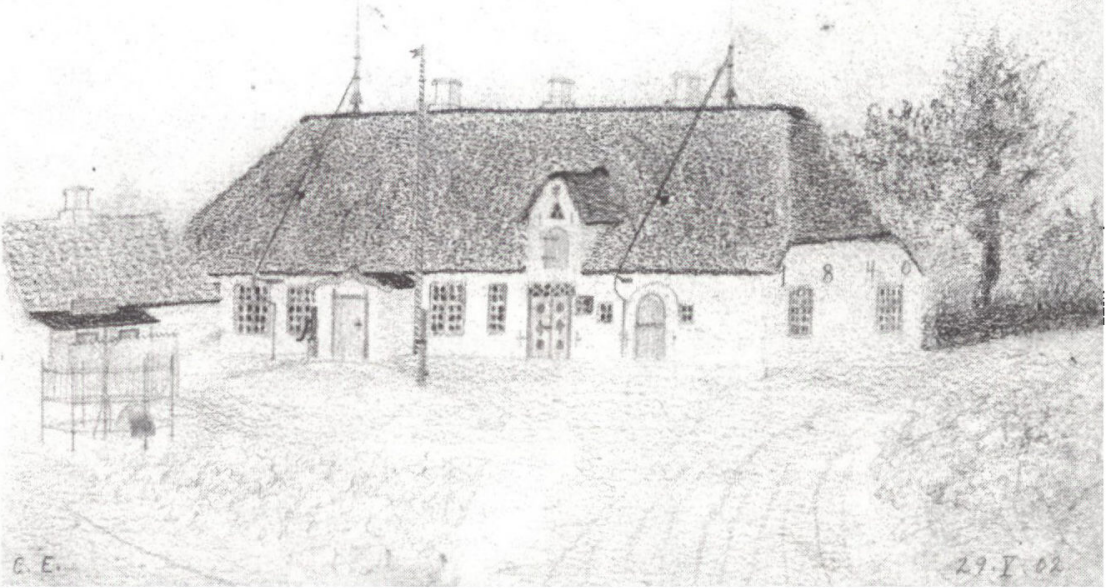

Skolen i Sad, tegnet den 29. maj 1902. Fra Claus Eskildsens skitsebog. (Privateje)

mine elever til sportskampene der, og da vi stillede de bedste hold, var det naturligt, at jeg kom i det udvalg, der ordnede disse kampe og til sidst havde hele det tekniske arbejde ved planlæggelsen og gennemførelsen af lege og idræt i forbindelse med det årlige stævne. Men jeg har end ikke oplæst resultaterne fra disse øvelser eller uddelt sejrskransene og langt mindre holdt nogen tale, har heller næppe som tilhører stået under talerstolen. For mig og de fleste andre var Knivsbjergfesten det årlige sportsstæune for landsdelen.

Hvad talen for kejser Wilhelm angår, er sammenhængen denne: Pligten til at holde en tale på kejserens fødselsdag gik på skift i kollegiet; men det var mere et fagligt foredrag, sluttende med et leve for kejseren; jeg mindes således at have hørt en sådan »kejsertale« behandle et emne fra lydlæren. I 1913 var det min tur, og jeg holdt denne såkaldte tale for kejseren, idet jeg ud fra to lige udkomne bøger (Paul Rohrbach: Der deutsche Gedanke in der Welt, og en anonym forfatters bog "Wenn ich der Kaiser wär' «) behandlede forfaldstegnene i tysk åndsliv og politik. Det var for resten en stærk reaktionær tale, svarende til, at jeg stod som medlem af Agrarpartiet, bl.a. fordi jeg ikke kunne tænke mig at være medlem af det skarpt danskfjendtlige nationalliberale parti, og min indstilling til politiske og sociale problemer forbød mig at slutte mig til andre partier. Det kan måske interessere Dem at høre, at det 
dengang var utænkeligt, at en lærer kunne være socialdemokrat; han ville have giort sig helt umulig!

Konflikten mellem det dybt liggende danske sind og den påtagne tyskhed, man skulle vise udadtil, lå som et stadigt tryk på mig. Derfor kom Genforeningen som en stor personlig befrielse. Da historien stillede os, den dalevende generation på den gamle kampplads, det spørgsmål: Skal dette land med rette høre til Danmark eller til Tyskland? var jeg ikke et øjeblik i tvivl. Denne gang brød jeg broerne af, sagde nej til en ærefuld opfordring til at overtage stillingen som overlærer og stedfortrædende forstander for Det kongelige preussiske Centralinstitut for gymnastik i Berlin, gjorde mig overhovedet umulig som lærer i den tyske stats tjeneste uden at vide, om den danske stat kunne eller ville bruge mig. Min deltagelse $\mathrm{i}$ afstemningskampen som taler på dansk side blev meget kort, fordi den internationale kommission meget snart forbød alle tjenestemænd at optræde som talere. Til gengæld førte jeg pennen ret flittigt $i$ afstemningstiden.

Det er muligt, at mit ivrige arbejde $i$ den danske sags tjeneste $i$ de sidste 25 år nu for de psykologisk skolede elever vil stå som et kompenseringsfænomen. Om dette er rigtigt, kan jeg ikke sige, da kompenseringen som bekendt er ubevidst. Men når jeg nu tager min afsked, vil jeg udtale, at jeg især er taknemmelig for de sidste 25 år, hvor man har kunnet ånde frit uden at være under stadigt tryk fra nationale samvittighedskonflikter, og de unge her onsker jeg til lykke med, at de har valgt en gerning, hvor erhvervsinteresser $i$ det daglige arbejde og samvittighed ikke som i mange erhverv kan komme i strid med hinanden. Det kan være nok at minde om bondens hestehandler, avancer $i$ de frie erhverv, sagførerkonflikter og andet, som vi lærere er lykkeligt forskånede for.

\section{II}

Jeg sagde, at jeg de sidste 25 år har kunnet ånde frit i national henseende; dette betyder ikke, at friheden som sådan, $\mathrm{i}$ al almindelighed, var ukendt under det tyske styre. De må ikke forestille Dem Preussen som et stort tugthus og Danmark som et ubunden frihedens Paradis. Det kan være nok at vise hen til to ting: Det danske eksamenskineseri i forhold til de frie tyske eksamensformer og det stive danske bureaukratiske centralstyre $\mathrm{i}$ forhold til den meget friere tyske decentralisering eller minde om, at vi i Tønder, da jeg kom dertil, kun havde én 
politibetjent, og han syntes ikke at være overbebyrdet. Det var mere ånden, der skabte forskellen mellem tysk tvang og nordisk-dansk frisind; men den, der ikke havde lært nordisk frisind at kende, der fra barnsben ikke kendte andet end preussiske forhold, følte ikke dagligt, at han levede $i$ et tvangens land. Jeg har heller ikke følt det, hverken som elev eller lærer.

Da jeg var 15 år gammel, kom jeg på den kongelige preussiske præparandanstalt i Åbenrå. Jeg er så gammel, at jeg måtte dispenseres fra en ældgammel bestemmelse fra den danske tid om, at de unge skulle have haft et års praktik ved en skole, inden de kunne optages på et seminarium. Den sædvanlige vej til læreruddannelsen begyndte dengang $\mathrm{i}$ en landsbyskole, hvor den unge assisterede læreren i lærergerningen samtidig med, at han under lærerens vejledning forberedte sig til seminariets optagelsesprøve. Dette førte til, at særlig dygtige lærere samlede små grupper af unge aspiranter, så der opstod små private præparandanstalter. Her i Vestslesvig havde Kaper i Lindholm, ${ }^{5}$ borgmester Kapers bedstefar, og Iversen i Bredebro, ${ }^{6}$ tandlæge Iversens bedstefar, sådanne små forberedelsesskoler ved siden af deres lærervirksomhed. I firserne oprettede den preussiske stat så to kgl. præparandskoler i hertugdømmerne, en i Åbenrå for Slesvig, en i Barmstedt for Holsten, hvortil først ved århundredskiftet kom to andre, en i Kappel for Slesvig, en i Lunden for Holsten. Da de langtfra kunne uddanne alle, der søgte ind på hertugdømmernes 6 seminarier, var tilstrømningen naturligvis overvældende og optagelsesprøven ret streng.

Læreruddannelsen varede altså dengang 5 år, 2 år på en præparandanstalt og 3 år på et seminarium. Når man var dimitteret fra seminariet, var man kun »Schulamtskandidat《. Den endelige kvalifikation til fast ansættelse erhvervede man ved en såkaldt »anden lærerprøve«, der kunne aflægges tidligst to år og skulle være bestået senest 5 år efter dimissionen. Indtil 1901 var denne uddannelse ret dårligt organiseret, idet seminarieundervisningen på mange måder var en gentagelse af det, man havde lært i præparandklasserne, og selv anden lærerprøven $i$ hovedsagen håndhævedes som en kundskabsprøve. Lidt efter århundredskiftet kom der plan i uddannelsen. De fleste seminarier blev indrettet som 6 klassede skoler med 3 praparand- og 3 seminarieklasser, og den tørre stoflige gentagelse blev hindret ved en fornuftig stoffordeling. I de 3 præparandklasser blev der med en god folkeskoles stof som grundlag indterpet kundskaber, så det forslog noget: bibelhistorie og katekismus, lange salmer og bibelsprog og hele kapitler $\mathrm{i}$ biblen uden- 
ad, tyske digte og prosatekster udenad, årstal og navnerækker i historie, bjerge med deres højder, floder og byer med indbyggertal i geografi, plante- og dyrenavne i naturhistorien, læresætninger i matematik og fysik o.s.v. Det var en fornøjelig undervisning, en åndelig sport, en hukommelsens cirkuskunst, passende til de unge i alderen 15-18 år. Når de så havde bestået afgangsprøven fra seminariets præparandanstalt, var de optaget på seminariet, og så sagde man til dem: Nu er det stoflige grundlag i orden; nu bygger vi videre på det. I stedet for bibelhistorier fik de nu historie med moderne bibelkritik, kirkehistorie og dogmehistorie, i tysk på grundlag af de digterbiografier, de havde lært $i$ præparandklasserne, en grundig litteraturhistorie, $i$ historie de store linier trukket op, i geografitimerne geologi, erhvervs- og handelsgeografi, astronomi o.s.v. Men frem for alt fik de på seminariet en grundig pædagogisk-metodisk uddannelse, psykologi og opdragelsens historie ikke blot, men også teoretisk metodik for hvert fag og hvert skoleår og hvert klassetrin og en grundig praktisk øvelse. Hele undervisningen $i$ en fireklasset og en enklasset øvelsesskole blev dengang nemlig udelukkende givet af eleverne i seminariets ældste klasse; der var ikke en eneste fast lærer ved øvelsesskolen. En af seminarielærerne, i reglen den yngste, havde som "Ordinarius der Seminarübungsschule" ledelsen af skolen og hovedtilsynet og som sådan ca. 10 timer om ugen det specielle timetilsyn. Der var nemlig hver time tilsyn fra en seminarielærer, der gik fra klasse til klasse, og som af de unge kunne tilkaldes, når en af drengene skulle tærskes; det måtte seminaristerne ikke gøre selv.

Klø vankede der nemlig nok af $\mathrm{i}$ denne skole, og det er meget naturligt, når man tænker på, at børnene i deres 9-årige skoletid i alt havde 270 lærere. Dér måtte disciplinen bygges op på et lydighedsforhold, da det personlige forhold manglede helt, og det blev naturligvis for enhver dreng af ære en sport at være med til at prøve, hvor langt man kunne gå med at drille den arme seminarist. Denne øvelsesskoleordning gav god øvelse for seminarieeleverne, der naturligvis indleverede skriftlige forberedelser dagen $\mathrm{i}$ forvejen, men den gav hårdkogte børn, selv om de bedste og dygtigste kunne lære uhyre meget, da begyndere som bekendt har vanskeligt ved at finde begrænsningens kunst og mange af de unge seminarister derfor fyldte børnene med professorviden - Værst var ånden $\mathrm{i}$ den enklassede skole, der havde lokale, hvor nu Frandsen ${ }^{7}$ bor. Her undervistes ca. 20 drenge i alderen 6-15 år samtidigt i samme lokale. Drenge fra Tønder kommune, hvis forældre ikke kunne eller ville betale skolepenge i den dyre mellemsko- 
le, var tvangsindskrevne i seminariets øvelsesskole; men for at få børn til den enklassede skole blev alt skolemateriale her givet børnene gratis, hvad man ellers ikke kendte i de tyske skoler. Det var altså en udpræget fattigbørnsskole med en stor del meget svagt begavede børn fra ikkeskoleinteresserede hjem, så undervisningen $\mathrm{i}$ denne skole af mange grunde var ret vanskelig for unge elever.

Lad mig lige nævne, at også anden lærerprøven noget efter århundredskiftet blev gjort fornuftig. Den blev nu aflagt på den måde, at læreren efter at han havde indsendt en skriftlig afhandling om et selvvalgt metodisk emne fra sin undervisning, en dag efter forudgående anmeldelse fik besøg af regeringsskoleråd, amtsskolekonsulent (kredsskoleinspektør) og en seminarielærer fra det nærmeste seminarium. Disse overværede undervisningen $i$ et par timer, gik derefter ind $i$ lærerens private stuer, hvor der stilledes ham nogle spørgsmål ang. metodik, praktik, kendskab til skolelove o.lign., og så var eksamen klaret og læreren fik fast ansættelse i folkeskolens tjeneste.

Han kunne derefter, når han var dygtig og flittig nok, aflægge to frivillige eksaminer. Mellemskolelærereksamen, der var en videnskabelig prøve i to fag, man valgte efter interesse, gav berettigelse til at få ansættelse ved mellemskoler og præparandanstalter: rektor-eksamen, der var en pædagogisk-metodisk eksamen af videregående art, gav kvalifikation til at blive overlærer ved en folkeskole eller seminarielærer. Jeg personlig har foruden første og anden lærerprøve, mellemskolelærer- og rektoreksamen efter et halvt års ophold på Centralinstitutet for gymnastik i Berlin desuden aflagt gymnastik- og svømmelærereksamen, så jeg næsten har drevet eksamenslæsning, helt til verdenskrigen rev mig ud af skolearbejdet.

Efter verdenskrigen blev læreruddannelsen $\mathrm{i}$ Tyskland atter helt lagt om, idet lærerne på en måde blev stillet lige med akademikerne. Alle seminarier blev nedlagt og uddannelsen lagt hen til lærerakademier $\mathrm{i}$ forbindelse med universiteter eller tekniske højskoler. Som forudsætning for optagelse på lærerakademiet krævedes studentereksamen, der dog også kunne tages på en såkaldt "Aufbauschule«, en ny form for højere skoler, bygget på folkeskolen med tysk og historie som hovedretning under tilsvarende nedskæring af kravene $i$ fremmede sprog. Uddannelsen på akademiet varer 2 år og er rent pædagogiskmetodisk-praktisk. Det er for resten dette akademi med 500 elever, der fra Kiel er flyttet til Flensborg.

Fordelene og manglerne ved denne sidste ordning kan man let se, lige som enhver af Dem vil kunne se fordelene ved den tidligere tyske 


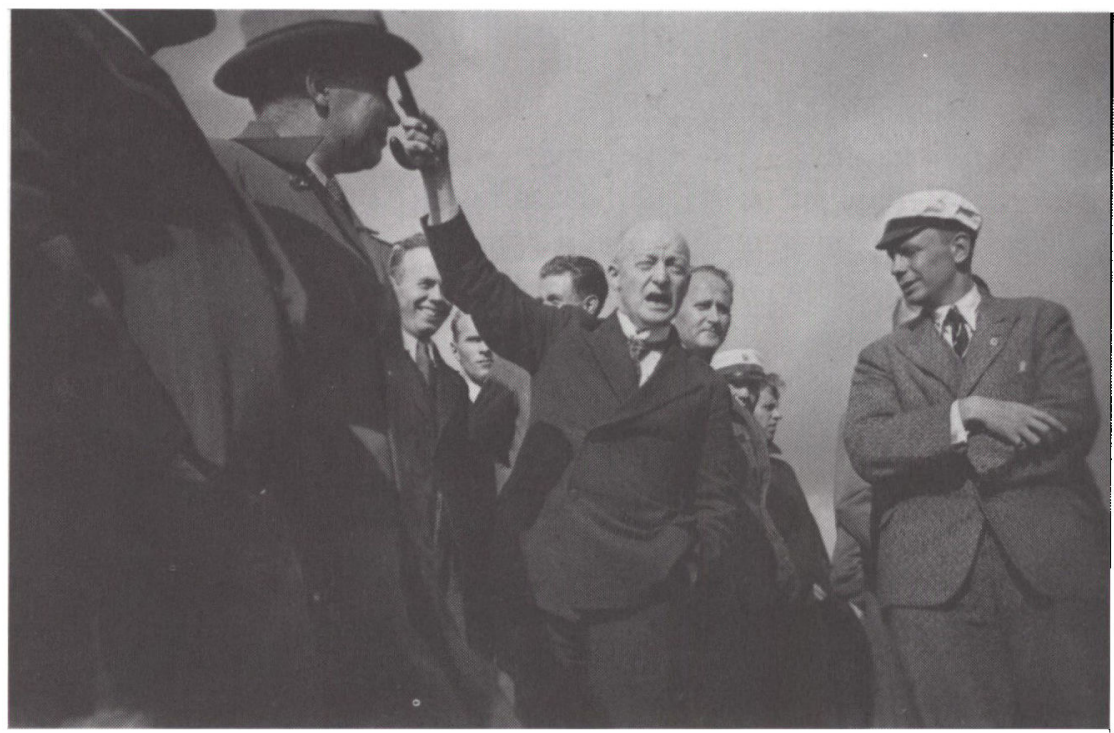

Claus Eskildsen $i$ en karakteristisk situation som leder af ture ud til de historiske steder. Her havde seminariet beseg fra Göteborg. (Privateje)

uddannelse i forhold til vor danske: en fornuftig plan i det stoflige, en stærkere fremhævelse af det pædagogisk-metodisk-praktiske.

Dermed vil jeg aldeles ikke rose den tyske lærerstand $\mathrm{i}$ almindelighed på bekostning af den danske. De tyske lærere fik en bedre praktisk uddannelse, blev på seminariet gjort bekendt med alle skoleformer, alle klassetrin, alle fags metodiske særpræg. Men det vigtigste har altid været ånden i en skole, og den jævne danske lærer i det frie, demokratiske Danmark vil i almindelighed have lettere ved at komme i kontakt med børnene og leve sig ind $\mathrm{i}$ barnets verden end den tyske lærer fra et mere autoritært samfund, der trods al sin gode teknik ofte vil være noget stiv og fremmed over for barnet. Naturligvis fandtes der også $\mathrm{i}$ den tyske lærerstand utallige store børnevenner, der helt gik op i samlivet med børnene, medens mange danske lærere naturligvis kan være kolde håndværkere i deres gerning. Måske rammer amtsskolekonsulent Svendsen ${ }^{8}$ bedst forholdet mellem danske og tyske lærere $\mathrm{i}$ almindelighed ved at sige: $\gg$ Har jeg valget mellem en dygtig dansk og en dygtig tysk lærer, vælger jeg den danske; har jeg valget mellem dårlig dansk og en dårlig tysk lærer, vælger jeg den tyske.« Denne vil i det mindste have teknikken i orden og aldrig stå helt hjælpeløs. 
Jeg vil da slutte dette afsnit om læreruddannelse med en alvorlig formaning, som et langt lærerlivs mange erfaringer giver mig retten og pligten til at fremsætte: Gør Dem flid på at supplere det danske med det bedste $\mathrm{i}$ den tyske læreruddannelse! De skal frem for alt og helt igennem være danske lærere, kærnedanske, jævne, folkelige, vindende danske, og De skal hverken søge at kopiere det tyske eller at agere små amerikanere. Men det vil kun gavne Dem og hele vor lærerstand, hvis der i den danske skole blev lagt større vægt på det rent metodiske. Det er ingen hemmelighed, at vi preussisk-uddannede lærere i de første år efter genforeningen ved instruktionskursus og lignende flere gange blev ligefrem chokerede ved at iagttage de allergroveste overtrædelser af de mest elementære metodiske didaktiske regler særlig i spørgeteknikken, som man hidtil ellers kun havde mødt dem i præsternes berømte konfirmandoverhøringer, og som jeg senere har mødt dem ved danske eksamensborde. Læreren skal helst være kunstner, og det vigtigste hos en lærer er instinktet, den medfødte evne til at komme i forbindelse med barnet og til at gøre stoffet interessant og let for dette; men selv de dygtigste kunstnere skaber intet stort uden teknisk kunnen, og mange lærere er nu engang ikke fødte kunstnere og kan derfor aldrig blive det. Men de kan ved flid og øvelse blive meget gode håndværkere $\mathrm{i}$ faget og grænsen mellem kunst og håndværk vil altid være flydende. Dette bliver man kun ved at tilegne sig fagets teknik og lægge vægt på gode arbejdsmetoder. Spørg en landmand, en håndværker, en købmand, enhver mand i det praktiske liv! De vil alle stadfæste, at gode arbejdsmetoder sparer både tid og̀ kræfter, læreren kan spare tid og kræfter for sig selv og børnene ved at tilegne sig gode læremetoder, og begyndelsen hertil skal gøres på seminariet. - Jeg minder i denne forbindelse blot om, at brugen af den middelalderlige barbariske stavemetode i småbørnsundervisningen i grænselandet med rette betragtes som en plet på den danske skole.

Skal seminarieeleverne imidlertid blive dygtige metodikere, skal de helst være fri for dagligt at se metodiske fejlgreb praktiserede af deres egne lærere. Ud fra dette synspunkt vil det være et vist tilbageskridt, når den gamle seminarielærertype nu går $\mathrm{i}$ graven, når $\mathrm{i}$ fremtiden seminarielærerstanden udelukkende rekrutteres fra unge akademikeres rækker, og disse burde, inden de fik lov til at undervise på et seminarium, gennemgå et kursus i elementær metodik og didaktik og helst have nogle års praktisk gerning i folkeskolens tjeneste bag sig, inden de blev lærer ved den skole, der skal uddanne praktiske lærere til folkeskolen og ikke mislykkede miniatureudgaver af akademikere. 


\section{III}

Fra 1896-98 var jeg elev på den kgl. præparandanstalt i Åbenrå, fra 1898-1901 på det kgl. skoleseminarium i Eckernførde - private lærerseminarier kendtes ikke i Tyskland - og straks efter dimissionen trak vi så godt som alle i min klasse i soldatertrøjen. Tjenestetiden $\mathrm{i}$ den tyske hær var kort forinden sat ned fra 3 år for alle våbenarter til 3 år for kavalleriet og 2 år for infanteriet. Alle, der havde bestået studenter- eller realeksamen, havde imidlertid ret til at nøjes med 1 år som "Einjährig-Freiwillig", mod at de til gengæld bekostede hele uddannelsen, uniformer, udrustning, ophold, af deres egne lommer. Reserveofficersstanden rekruteredes udelukkende fra disse frivillige rækker, så officersstandens eksklusive karakter kunne bevares. For lærerne gjaldt der indtil 1900 særlige regler, idet de kun blev uddannede i alt 20 uger, fordelt på flere år, som »Ersatz-Reservister«, d.v.s. erstatning for reserven, altså erstatning for erstatning. Lærerstanden kæmpede i mange år mod dette pariastempel og opnåede, at lærerne fra 1901 af fik 1 års uddannelse sammen med de etårige-frivillige, enten under samme vilkår som disse, hvorved man fik adgang til reserveofficersstanden, eller som "Staatseinjährig" på statens bekostning, hvorved man måtte nøjes med adgangen til underofficersstanden. Fra lærerorganisationernes side blev der agiteret stærkt for, at de unge lærere skulle udnytte privilegiet som »Etårig-frivillige« og altså skaffe sig adgang til reserveofficersstanden, der i Preussen var det ydre tegn på, at man tilhørte samfundets første klasse, meget højt hævet over det almindelige rak. Det blev senere også almindeligt, at lærerne bekostede deres militære uddannelse selv, men vi, det første hold, foretrak alle at forblive i underklassen og lade os uddanne på statens bekostning. Jeg har aldrig fortrudt, at jeg sparede de mange rare penge. Fra den første dag, vi fik de blanke knapper og fuldstændig chokerede stod over for den preussiske militarismes råhed, amoral og menneskeforagt og indtil verdenskrigens afslutning, da jeg havde tilbragt næsten 6 år af mit liv i militærtjenesten, har jeg afskyet dette væsen, og jeg ville have ærgret mig endnu i dag, hvis jeg skulle have ofret en sum, der dengang betød en lille formue for os, på uddannelsen. Nu fik vi i det mindste som gengæld for vort legemlige slid og vore åndelige lidelser den fyrstelige gage af 22 penning om dagen.

Om mine $4 \frac{1}{2}$ års deltagelse $\mathrm{i}$ verdenskrigen har jeg fortalt andet steds. ${ }^{9} \mathrm{Jeg}$ vil blot også ved denne lejlighed bekende som min opfattelse, at krigen er alle ulykker og hjemsøgelser $i$ en hovedsum: død og brand 
og sult og pest, ondskab og løgn, ødelæggelse af alle gode værdier og utrolig ødselhed, nedbrydning af alt, der skulle føre menneskeheden fremad. - Det er med den allerdybeste skuffelse, at min generation, der har forvaltet fædrenes arv så slet, at vi to gange har styrtet verden ud i krigens ubeskrivelige rædsler og ubodelige ulykker, ikke kan give den slægt, der kommer efter os, et håbets ord om den evige fred, der helt siden tidernes morgen har strålet for menneskenes blik som fremtidens store nytid, mest lysende tegnet af Israels gamle profeter. Mange troede på den efter den første verdenskrig, da idealisten Wilsons udødelige idé om et Folkenes Forbund var ved at blive virkelighed. Vi står efter denne krig sunket dybt ned i håbløshedens sump. Gid De, når De bliver gamle, over for Deres efterslægt måtte kunne pege hen på et morgenrødens skær: udsigt til et frembrud for fred for den arme jord, bygget på folkeforsoning, respekt for det enkelte menneskes og folks frihed, værdsættelse af de opbyggende kulturelle, sociale, etiske og religiøse værdier!

\section{IV}

Jeg skulle nu fortælle Dem om min første lærevirksomhed som lærer ved den enklassede skole i Sæd med 65 børn, hvor altså disse børn i alderen 6-15 år blev undervist samtidigt i samme lokale. Jeg skulle fortælle om begyndelsen til det danske seminarium i Tønder, der på en smuk måde har fortsat det bedste i dette steds gamle traditioner, om det første lærerkollegium på dette sted, om hvilket der kan citeres:

Nur eine hohe Säule zeugt von verschwundner Pracht, und diese, schon geborsten, kann stürzen über Nacht!

Jeg skulle fortælle om elevliv på seminariet $\mathrm{i}$ den danske og den tyske tid, om mit arbejde som medlem af byrådet $i$ den tyske tid og formand for ligningskommissionen i den danske. ${ }^{10} \mathrm{Jeg}$ skulle frem for alt fortælle om erfaringer $\mathrm{i}$ arbejdet med børn og især småbørn. Alt dette bliver der ikke tid til. Jeg må slutte af.

De vil dog meget naturligt sidde med ét spørgsmål, som jeg skulle svare på: Hvordan ser sådan et gammelt menneske mon på os, ungdommen fra i dag?

Dertil må jeg først sige, at jeg ikke aner noget om, at jeg er gammel, d.v.s. ikke føler det. Jeg bør takke Gud - og en god, rolig, omsorgsfuld 


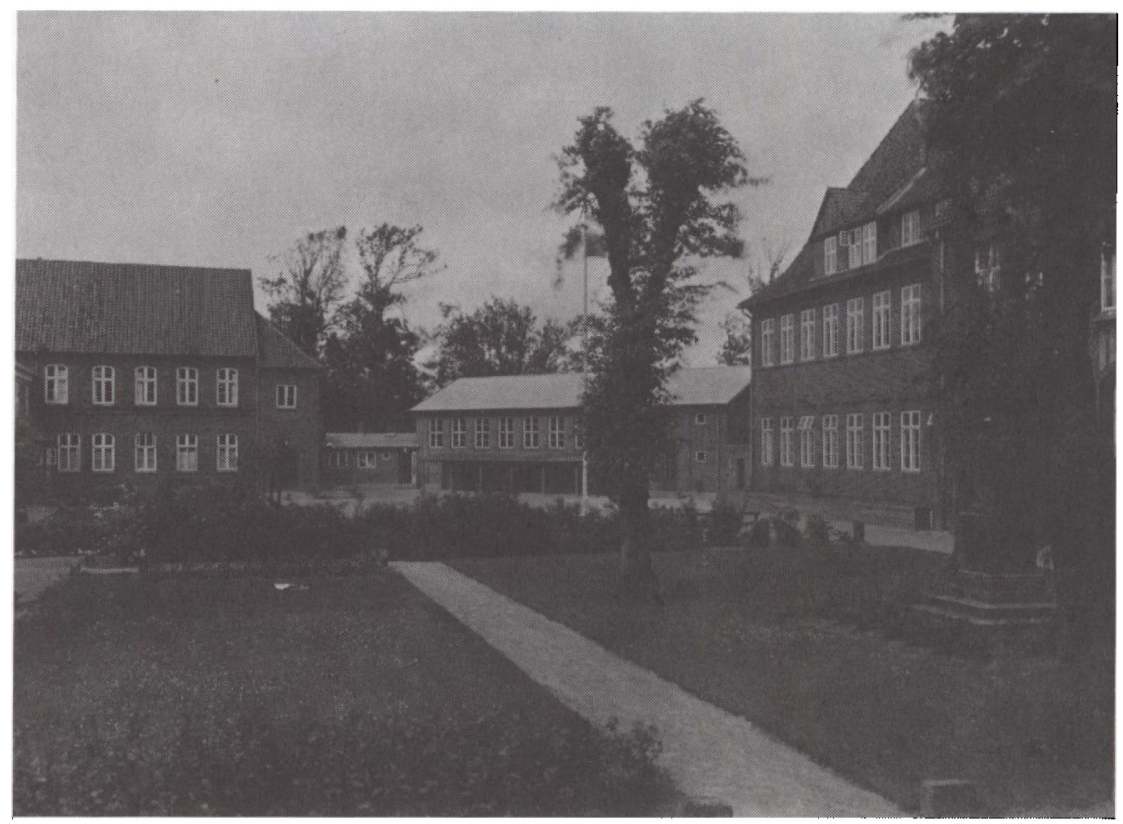

Et kig ind $i$ Tonder Statsseminariums gård, som der så ud i 1940'rne.

kone - for et godt helbred. Jeg har ikke haft én sygedag i de 40 år på seminariet, hverken i den tyske eller danske tid, bortset fra et par dage, da jeg lå med hjernerystelse, fordi en elev i idrætstimen havde kastet mig en jernstødkugle $\mathrm{i}$ hovedet, og et par andre dage, da jeg på sportspladsen havde hentet mig et ankelbrud. Det var dog kun et par dage, jeg var fraværende; idet jeg på 3. dag med benet i skinner og gibs lod mig transportere til mine undervisningstimer $\mathrm{i}$ båd; jeg boede dengang ved Sønderport. Jeg har stadig så gode nerver, at jeg kan sidde og arbejde intensivt $\mathrm{i}$ en snakkende kupé, derefter holde to lange foredrag om dagen og ind imellem og efter kan sidde og agere midtpunkt i en selskabelig kreds, selv om jeg indrømmer, at det sidste er det værste. Med undtagelse af hukommelsen for personnavne mærker jeg heller ikke selv en aftagen af åndsevnerne, endskønt denne naturligvis er til stede. Jeg føler frem for alt ikke de 44 års virksomhed i opdragelsens tjeneste som en lang tid, tværtimod! "Thi hastigt går det, vi flyver af sted! « siger den gamle israelit med rette i en af de mange salmer, vi lærte udenad.

Når jeg går nu, er det altså ikke, fordi jeg selv føler mig gammel og træt eller ikke skulle have lyst til arbejdet, men fordi jeg på forhånd 
havde taget den beslutning at gå med 65 år. Jeg har set hos så mange, at de ved den tid var gamle, uden at de selv vidste det, at jeg ved, at det samme naturligvis er tilfældet med mig selv. Jeg agter ikke at blive ved som en gammel faldefærdig ruin, hvis forsvinden kollegaer og elever venter på med længsel.

Og når jeg bruger min eftertanke, skal jeg også bekende, at jeg er gammel! Lad mig nævne Dem et par små sære ting, der for Dem lyder som stammende fra middelalderen: I vort barndomshjem hyggede vi os om aftenen omkring den første petroleumslampe, der var kommet til denne by, de gamle kunne endnu fortælle om sivlampen. På præparandanstalten i Åbenrå var belysningen i klasserne endnu åbne gasblus, og da glødestrømperne til gas kom, virkede de på os som et under; elektrisk lys var dengang helt ukendt i små købstæder. Jeg har med 15 år for første gang siddet på en cykel, jeg har set de første automobiler, det første luftskib, den første flyvemaskine. Jeg har for første gang $\mathrm{i}$ mit liv telefoneret, da jeg var ung lærer. Da jeg kom til Tønder, blev vandværket bygget; borgerne havde indtil den tid hentet deres vand ved åbne brønde eller ved åen. Kloakering med vandkloset og andre bekvemmeligheder $\mathrm{i}$ følge fik vi først efter 1920. Alt spildevand fra køkken, vaskehus, toiletter og stalde løb fra smøgerne mellem husene ud $\mathrm{i}$ gadens rendestene, og på fortovene dannede der sig om vinteren hele isbræer, som man balancerede hen over, når man om morgenen gik til klassen. Jeg har oplevet, at byen fik sit elektricitetsværk, sin første realskole, sin første sportsplads. Jeg har set kvinder med lange opkiltrede skørter, med pufærmer og snøreliv og mænd med de lange, snævre bukser med knæ i. Jeg har med oprigtig forargelse set de første kvinder ryge og med lige så stor foragt set de første mænd ryge cigaretter. Jeg har $\mathrm{i}$ en sen alder spist den første banan, den første tomat, den første melon. Jeg har stadig ikke fået lært at gå med gummiregnfrakke og paraply eller med galocher og gummistøvler. Jo, jeg skal jo være en gammel mand!

Men så gammel er jeg dog ikke blevet, at jeg skælder ud på den fordærvede ungdom, som de gamle har gjort det siden Adam og Evas dage. Ungdommen har forandret sig meget siden dengang, da vi var unge; på nogle områder er den måske mere fordærvet, end vi var det, på andre er den bedre, så det som helhed turde gå lige op. Jeg vil snarere være tilbøjelig til at give ungdommen fra $\mathrm{i}$ dag prisen, når vi sammenligner den med ungdommen for 50 år siden. Den er mindst lige så interesseret, som vi var det, den er frem for alt mere frigjort, åben, arlig, ligefrem. 


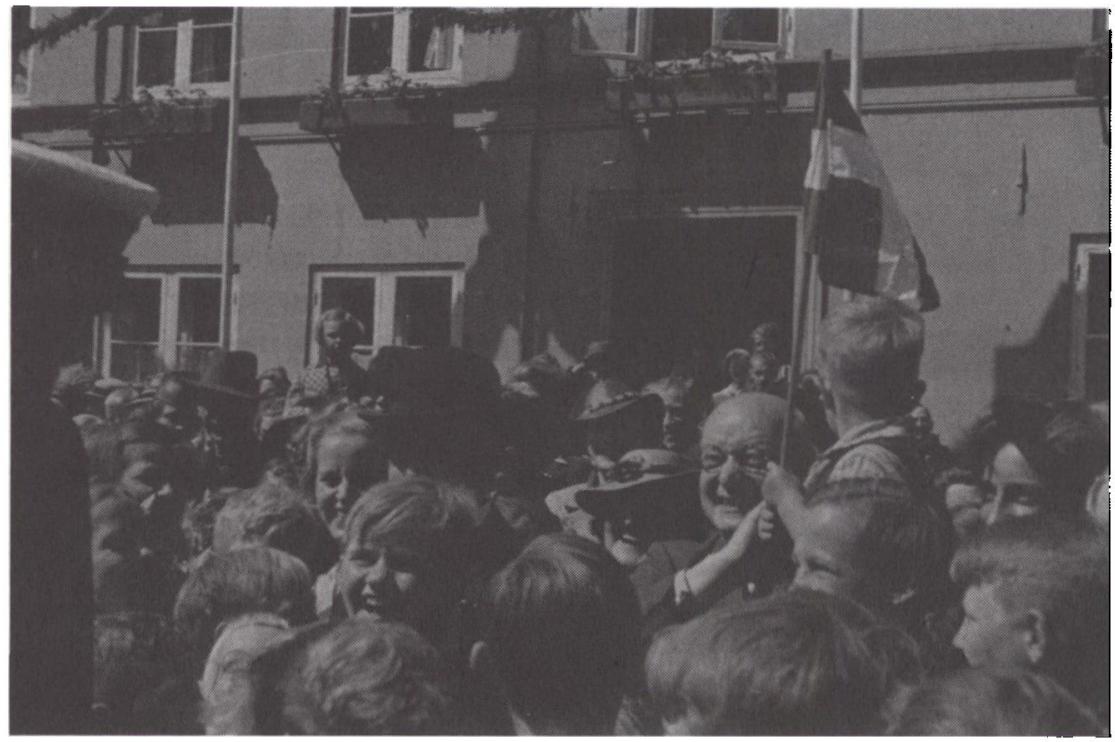

Fra en kongemodtagelse $i$ Tonder. Kong Christian 10. skimtes til venstre. Midt $i$ billedet ses en glad Claus Eskildsen med en lille dreng på armen. I fallesskab barer de flaget. (Privateje)

Dette har dog også sin skyggeside, idet denne side af det menneskelige væsen kan udvikles for stærkt. Frigjorthed kan blive til løssluppenhed fra alle bånd, også de almindelige moralske; åbenhed og ærlighed kan blive til frækhed og tilsidesættelse af den naturlige respekt for autoritet, som er en vigtig grundpille i samfundslivet, og til mangel på sans for orden og præcision, der ikke mindst på skolens område er af stor vigtighed. Jeg vil da ønske for Dem, mine elever, at De bevarer Deres dejlige naturlighed og friske åbenhed og bliver så stærke mennesker, som kun friheden kan frembringe; men at De fra vor svundne tids ungdom overtager følelsen af $i$ al frihed at være bunden af de faste love, ethvert godt samfund skaber, og hvis tilsidesættelse skal medføre samfundets opløsning. Sand frihed for den enkelte eksisterer kun sammen med underordning under et lovbundet samfunds regler.

Så vil jeg slutte med allerførst at rette en tak til de 26 årgange af småbørn, der har glædet mig og holdt mig ung ved deres lysende, strålende øjne og deres rene, primitive sind. Jeg takker dernæst de lige så mange årgange seminarieelever, der har vist modtagelighed over for det, jeg søgte at give, venlighed mod mig som lærer og menneske og overbærenhed med mine faglige mangler og menneskelige brøst. Jeg 
takker mine kollegaer ved seminariet og øvelsesskolen for venlighed og venskab gennem mange år. Jeg mindes med tak og vemod de døde og med trofast venskab de fraflyttede. Jeg takker ikke mindst dette seminariums nuværende forstander for aldrig svigtende elskværdighed og imødekommenhed, hjælp og bistand i alle forhold.

Jeg ønsker hver enkelt af Dem et liv fyldt af arbejde og arbejdsglæde. Jeg ønsker denne gamle lærerskole en rig fremtid til velsignelse for den gamle by, for vort omstridte grænseland, for vort gamle danske folk og vor hele arme mistrøstige menneskehed, der i skuffelsernes mørke sidder ved små håbets blus og spejder efter det store retfærdighedens, tolerancens og kærlighedens varmende bål, som hver enkelt af Dem skal bære ved til.

Og dermed et oprigtigt farvel og tak!

\section{NOTER}

1. Forstander Morten Bredsdorff, der var leder af Tønder Statsseminarium fra 1937-1947. Bredsdorff har fortalt trak fra samarbejdet med Claus Eskildsen i Uddrag af dagbogsblade, Sjy Årb 1968, og Tønder Statsseminarium 1937-43, Sjy Årb 1974.

2. Claus Eskildsen var født i Felstedskov den 12. januar 1881, som søn af gårdejer Peter Eskildsen og Sille Marie, f. Festersen.

3. Eskildsen blev efter sin uddannelse i Eckernförde i 1902 lærer i Sæd og i 1903 gift med gårdmandsdatteren Caroline Johanne Lorenzen, Sxd. I 1905 blev Eskildsen præparandlærer ved Tønder Seminarium og i 1909 seminarielærer.

4. Peder Skovrøy (1851-1935), var fra 1882 redaktør af Vestslesvigsk Tidende, der $i$ 1885 blev sammensluttet med Flensborg Avis.

5. Ernst Lebrecht Kaper, født i Tønder 1815, død i Lindholm 1888, dimitteret fra Tønder Seminarium i 1836. Fra 1837 lærer i Nørre Lindholm. Borgmester, dr.phil. Ernst Kaper (1874-1940) rektor ved Ordrup Gymnasium 1908-1917, fra 1917 borgmester for magistratens 1. afdeling i København. Biografisk Leksikon sætter Ernst Lebrechts Kapers fødselsår til 1811, Børge Barløse i Tønder-Staten til 1815. På redaktionens opfordring har Børge Barløse undersøgt sagen. Kirkebogen i Tønder: Ernst Lebrecht Kaper, født 17.09.1815.

6. Jens Iversen (1817-1882) førstelærer og degn i Bredebro fra 1858-1882; oprettede den nævnte præparandklasse i 1861. Tandlæge Lars Peter Iversen, praktiserende tandlæge i Tønder fra 1916 til sin død i 1944.

7. Rasmus Frandsen (1883-1958), født i Logumkloster, var pedel ved Tonder Statsseminarium og øvelsesskole 1939-54.

8. Amtsskolekonsulent Nicolai Svendsen (1877-1966). Fra 1920 til 1946 amtsskolekonsulent i Tønder amt. Forud herfor redaktør af Dannevirke i Haderslev.

9. Bl.a. i Østfront-Vestfront, 1929.

10. Eskildsen var medlem af Tønder byråd 1909-1919; efter 1920 i ti år medlem af ligningskommissionen, deraf otte år som formand. 
